\title{
Schmerzhafte Rötung
}

\section{Was ist schuld an der Entzündung?}

Der 60-jährige Patient klagt über eine schmerzhafte Hautrötung im Stirnbereich, die sich nach einer kleinen Wunde vor einigen Tagen entwickelt hat. Er fühle sich zudem krank und habe auch Fieber. Die Rötung ist scharf begrenzt und weist einen wallartigem Rand auf.

-Was verursacht die Entzündung?

_Welche Therapie ist angebracht?

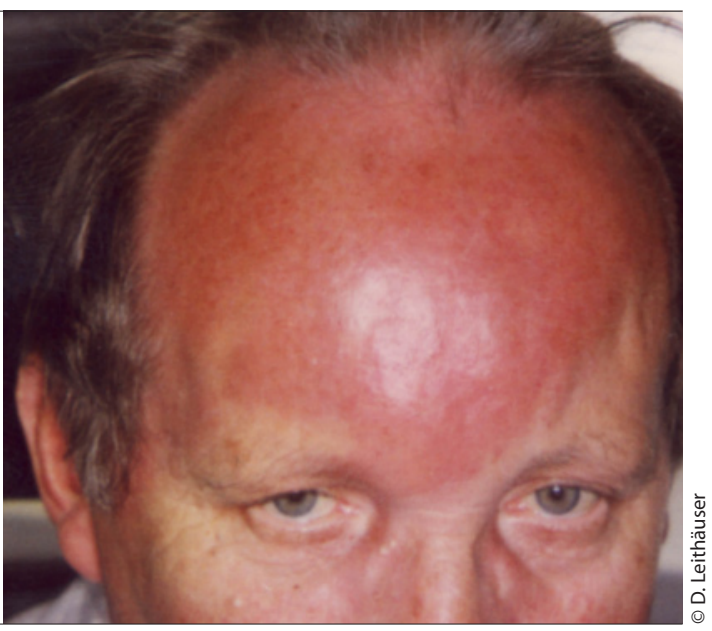

Zur Auflösung bitte umblättern

\section{Zeigen Sie Trockenheit eine lange Nase.}

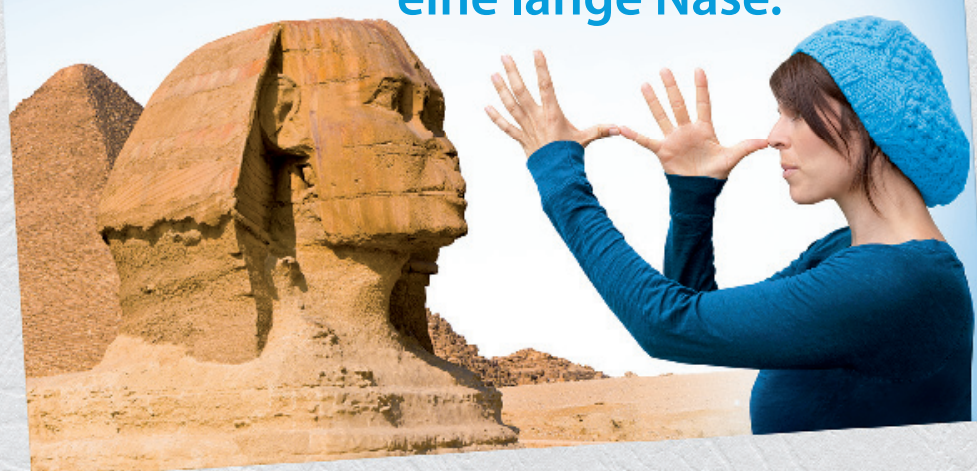

Feuchtigkeit für die Nase

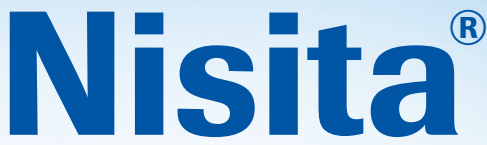

- Mit wertvollen Mineralsalzen

- Schützt die Nasenschleimhaut vor dem Austrocknen

- Löst sanft Verkrustungen

- Für Säuglinge und Kleinkinder geeignet

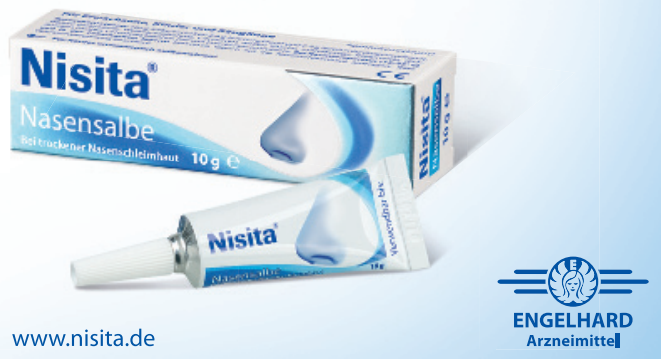

